\title{
OVERVIEW OF ANKLE BRACHIAL INDEX (ABI) VALUES ON DIABETES MELLITUS TYPE 2 IN BLITAR
}

\author{
Ulfa Husnul Fata \\ Nursing Study Program, STIKes Patria Husada Blitar \\ email: ulfaners@gmail.com
}

\begin{abstract}
Examination of foot vascularization often used for patients with DM who have Perypheral Arterial Disease (PAD) is to measure the value of Ankle Brachial Index (ABI). ABI examination is a noninvasive gold standard measurement to detect vascular disorders of the peripheral arteries and is recommended as part of the assessment process to help formulate the diagnosis in at-risk individuals. The purpose of this study was to provide an overview of the value of $\mathrm{ABI}$ in people with diabetes mellitus type 2 in Village ofKepanjenKidul and Village KarangsariBlitar City. The method in this research was descriptive with respondent of type 2 diabetes mellitus as much as 32 respondents. Methods of data collection with check list and ABI score. The results of this study indicated that the value of ABI in people with type 2 diabetes with $\mathrm{ABI}$ value right and left extremities borderline and abnormal categories at most are female gender, abnormal value many in diabetics who do not routinely consume anti diabetic drugs, abnormal ABI value many in patients who do not exercise regularly, abnormally abnormal $\mathrm{ABI}$ values in patients who have never performed foot therapy, and abnormal ABI values are many in patients who do not implement the diet. Therefore, foot examination was very important to be done regularly to reduce the risk of foot ulcers in patients with diabetes mellitus.
\end{abstract}

Keywords: ankle brachial index, ABI, diabetes mellitus type 2

Diabetes mellitus is a group pf metabolic diseases characterized by elevated blood glucose (hyperglycemia) as a result of abnormalities of insulin secretion, insulin activity or both (American Diabetes Association/ADA, 2009; Smeltzer, et al, 2010). Diabetes mellitus has become a major health problem because its complications are short-term and long term. One form of chronic somplications that often occur in people with diabetes mellitus is diabetic foot ulcer (Prompers et al, 2008).

An injury occurrence in the legsof patients with diabetes mellitus is a defect in the integument system of basic structure that can lead to damage to skin integrity and disturbance in physiological function of the network (Carville, 2007). Research conducted in the United States about $85 \%$ cases of lower limb amputation caused by diabetes mellitus that begins the foot ulceration. The occurrence of leg amputation every 20 seconds due to complications of diabetes mellitus (Boulton et al,
2008). Leg ulcers affect approximately $70 \%$ of these ulcers are primed by chronic venous insufficiency (CVI), with $20 \%$ to $25 \%$ being attributed to arterial or mixed disease (Nelson and Bradley, 2003; Bryant \& Nix, 2007: 258). It is difficult to accurately determine the prevalence and incidence of these ulcers and separately (Nelzen, Bergqvist, and Lindhagen, 1996; Bryant and Nix, 2007: 258)

Most cases of diabetic foot ulcers are the ultimate manifestation of peripheral neuropathy, vascular abnormalities or a combination of both because of poor blood sugar control conditions (Brownrigg, 2012). Examination of foot vascularization often used for patients with DM who have Peripheral Arterial Disease (PAD) is to measure the value of Ankle Brachial Index (ABI) (Potier, et al. 2011), using Doppler Ultrasound. Doppler ultrasound is used to measure blood flow in both arteries and veins. Measurement helps to 
determine the degree of arterial or venous disease in the leg (Carville, 2007). ABI examination is a non-invasive gold standard measurement to detect vascular disorders from peripheral arteries and is recommended as part of the assessment process to help formulate diagnoses in at-risk individuals (Migliacci, 2008). Inappropriateness in diagnosing PAD results in serious considerations such as functional capacity abatement, amputations, depression and quality of life.

Doppler ultrasound is a tool for translating arterial and venous blood flow. This checks for prevention of arterial or venous blood vessels. Examination is very helpful in establishing a proper nursing diagnosis process.Under normal conditions, the systolic pressure on the foot is equal to the hand or slightly higher. In the event of disturbance in the area of the foot, either venous or arterial disturbances, it will produce different systolic pressure. Accurate examination results may help diagnostically lead to venous or arterial disorders, so management of care is also different (Gitarja, 2008).

In addition to $\mathrm{ABI}$ examination, foot care is the primary prevention of injury to the diabetic foot. Measures to be performed on foot care for early foot abnormalities, proper nail cutting, good footwear usage, keeping foot and foot rest. Things that should not be done is to cope alone when there is a problem in the foot or with the use of sharp tools or objects. Patients need to know the care of diabetic feet well so that the incidence of gangrenous ulcers and amputations can be avoided (Tambunan, 2011).

Based on the description above, researchers are interested to conduct research entitled "Overview of Ankle Brachial Index in type 2 diabetes mellitus in Sananwetan and Sukorejo Community Health Center BlitarCity".

\section{RESEARCH METHODS}

This research was a descriptive research. The sample in this research was diabetes mellitus type 2 in work area of Sananwetan and Sukorejo Public Health Center of Blitar City in June 2017 with sample size 32. Sampling methode with purposive sampling according to inclusions and exclusions criteria. Sample inclusion criteria include: (1) patients with diabetes type 2, (2) long suvering with diabetes mellitus more than 1 year, (3) patient age above 40 years. While the exclusion criteria is patients with leg ulcers.
Data collection was conducted at Kepanjen Kidul and Karangsari Village, Blitar City. The researcher intifies the prospective respondents by conducting interviews and checks that are adjusted to the inclusion and exclusion criteria. After given informed consent, then filling the data collection sheet followed by ABI examination on each respondent. Univariate analysis includes ABI score, age, gender, random blood sugar, long diabetes, oral antidiabetic drug (ANTI DIABETIC DRUGS), exercise, smoking history, foot therapy, and diet. Data analysis was done to find out the ABI values in diabetes mellitus type 2 patients.

\section{RESULT}

Table 1 Distribution of respondents by age and blood glucose levels in the Village of Kepanjen Kidul and Karangsari, Blitar City, June 2017 (n = 32)

\begin{tabular}{lcccc}
\hline Variable & Mean & Median & SD & Min-Max \\
\hline Age & 56.66 & 56 & 8,015 & $42-73$ \\
\hline $\begin{array}{l}\text { Blood } \\
\text { Glucose } \\
\text { Levels }\end{array}$ & 289.91 & 291 & 64,593 & $182-410$ \\
\hline
\end{tabular}

Table 1 describe the results of the analysis of the mean age analysis of respondent in this study was $56,66 \pm 8,015$ years with the age range of $42-$ 73 years. While the average level of blood glucose analysis was $289,91 \pm 64,593$ with the range $182-$ $410 \mathrm{mg} / \mathrm{dl}$.

Table 2 Distribution of respondents by gender and diabetic drugs consumtion in the Village of Kepanjen Kidul and Karangsari, Blitar City, June $2017(\mathbf{n}=32)$

\begin{tabular}{lcc}
\hline Variable & Frequency & Persentage \\
\hline Gender & & \\
Male & 12 & 37,5 \\
Female & 20 & 62,5 \\
\hline Anti Diabetic & & \\
Drugs consumtion & & \\
Never & 7 & 21,9 \\
Not a routine & 17 & 53,1 \\
Routine & 8 & 25 \\
\hline
\end{tabular}

Table 2 describe the distribution of respondents that the majority of respondents were female that are 20 respondents $(62.5 \%)$, as well as the 
distribution of respondents by consumtion of the diabetic drugs most respondents did not routine consume diabetic drugs 17 respondents $(53.1 \%$.)

Table 3 Distribution of respondents by physical exercise, foot therapy, smoke history, and diet in the Village of Kepanjen Kidul and Karangsari, Blitar City, June $2017(\mathrm{n}=32)$

\begin{tabular}{lcc}
\hline Variable & Frequency & Persentage \\
\hline Physical exercise & & \\
Never & 7 & 21,9 \\
Not a routine & 19 & 59,4 \\
Routine & 6 & 18,8 \\
\hline Foot therapy & & \\
No & 31 & 96,9 \\
Yes & 1 & 3,1 \\
\hline Smoking history & & \\
Never & 25 & 78,1 \\
Past & 3 & 9,4 \\
Active & 4 & 12,5 \\
\hline Diet & & \\
No & 23 & 71,9 \\
Yes & 9 & 28,1 \\
\hline
\end{tabular}

Table 3 describe the frequency distribution indicating that the majority of respondent were not active in exercise of 19 repondents (59.4\%). Almost all respondents never did not foot therapy as much as 31 respondents (96.9\%). The results of smoking history analysis showed that the majority of respondents never smoked of 25 respondents (78.1\%), and the most respondents dit not implement diabetes mellitus diet as much as 23 respondents (71.9\%).

Table 4 Distribution of respondents by ABI values in the Village of Kepanjen Kidul and Karangsari, Blitar City, June 2017 ( $(\mathbf{n}=32)$

\begin{tabular}{lcc}
\hline Variable & Frequency & Persentage \\
\hline ABI right & & \\
extremity & & \\
Normal & 8 & 25 \\
Borderline & 11 & 34,4 \\
Abnormal & 13 & 40,6 \\
\hline ABILeft & & \\
extremity & & \\
Normal & 9 & 28,1 \\
Borderline & 9 & 28,1 \\
Abnormal & 14 & 43,8 \\
\hline
\end{tabular}

Table 4 showed that the value of $\mathrm{ABI}$ in right extremity is almost half abnormal of 13 respondents (40.6\%). Likewise with the left extremity that almost half of the respondent with ABI values in the abnormal category of 14 respondents (43.8\%).

Table 5 Cross tabulation of ABI values in right extremity by gender, Anti Diabetic drugs consumtion, exercise, smoking history, foot therapy, and diet in Village of Kepanjen Kidul and Karangsari, Blitar City, June 2017 (32)

\begin{tabular}{lcccccc}
\hline \multirow{2}{*}{\multicolumn{1}{c}{ Variabel }} & \multicolumn{6}{c}{ ABI Right Extremity } \\
\cline { 2 - 7 } & \multicolumn{1}{c}{ Normal } & \multicolumn{3}{c}{ Borderline } & \multicolumn{2}{c}{ Abnormal } \\
\hline Gender & \% & $\Sigma$ & $\%$ & $\Sigma$ & $\%$ \\
Male & 3 & 25 & 2 & 16.7 & 7 & 58,3 \\
Female & 5 & 25 & 9 & 45 & 6 & 30 \\
\hline Anti Diabetic & & & & & & \\
Drugs & & & & & & \\
Consumtion & & & & & & \\
Never & 2 & 28.6 & 2 & 28.6 & 3 & 42.8 \\
Not a routine & 4 & 23.5 & 6 & 35.3 & 7 & 41.2 \\
routine & 2 & 25 & 3 & 37.5 & 3 & 37.5 \\
\hline Physical & & & & & & \\
exercise & & & & & & \\
Never & 1 & 14.2 & 3 & 42.9 & 3 & 42.9 \\
Not a routine & 7 & 36.8 & 4 & 21.1 & 8 & 42.1 \\
routine & 0 & 0 & 4 & 66.7 & 2 & 33.3 \\
\hline Terapi Kaki & & & & & & \\
Yes & 0 & 0 & 1 & 100 & 0 & 0 \\
No & 8 & 25.8 & 10 & 32.3 & 13 & 41.9 \\
\hline Riwayat & & & & &
\end{tabular}

\begin{tabular}{lcccccc}
\hline $\begin{array}{l}\text { Riwayat } \\
\text { Merokok }\end{array}$ & & & & & & \\
Never & 8 & 32 & 9 & 36 & 8 & 32 \\
Pas & 0 & 0 & 1 & 33.3 & 2 & 66.7 \\
Active & 0 & 0 & 1 & 25 & 3 & 75 \\
\hline Diet & & & & & & \\
Yes & 1 & 11.2 & 4 & 44.4 & 4 & 44.4 \\
No & 7 & 30.4 & 7 & 30.4 & 9 & 39.2 \\
\hline
\end{tabular}

Table 5 indicates that type 2 diabetics with ABI values of the right extremity categories borderline and abnormal are female gender, abnormal values are high in diabetics who do not routinely consume anti diabetic drugs, abnormal ABI values are many in patients who do not exercise regularly, abnormal $\mathrm{ABI}$ values are many in patients who have never performed foot therapy, and abnormal ABI values are high in patients who do not carry out diet. 
Table 6 Cross tabulation of ABI values in left extremity by gender, Anti Diabetic drugs consumtion, exercise, smoking history, foot therapy, and diet in Village of Kepanjen Kidul and Karangsari, Blitar City, June 2017 (32)

\begin{tabular}{lcccccc}
\hline \multirow{2}{*}{ Variabel } & \multicolumn{5}{c}{ ABILeft Extremity } \\
\cline { 2 - 7 } & \multicolumn{2}{c}{ Normal } & \multicolumn{3}{c}{ Borderline } & \multicolumn{2}{c}{ Abnormal } \\
\hline \multicolumn{1}{c}{$\begin{array}{c}\text { Gender } \\
\text { Male }\end{array}$} & 2 & 16.7 & 2 & 16.7 & 8 & 66.6 \\
Femele & 7 & 35 & 7 & 35 & 6 & 30 \\
\hline Anti Diabetic & & & & & & \\
Drugs & & & & & & \\
Consumtion & & & & & & \\
Never & 3 & 42.9 & 1 & 14.3 & 3 & 42.9 \\
Not a routine & 4 & 23.5 & 6 & 35.3 & 7 & 41.2 \\
routine & 2 & 25 & 2 & 24 & 4 & 50 \\
\hline
\end{tabular}

\begin{tabular}{lcccccc}
\hline $\begin{array}{l}\text { Physical } \\
\text { exercise }\end{array}$ & & & & & & \\
Never & 3 & 42.9 & 1 & 14.3 & 3 & 42.9 \\
Not a routine & 5 & 26.3 & 5 & 26.3 & 9 & 47.4 \\
routine & 1 & 16.7 & 3 & 50 & 2 & 33.3 \\
\hline Terapi Kaki & & & & & & \\
Yes & 1 & 100 & 0 & 0 & 0 & 0 \\
No & 8 & 25.8 & 9 & 29 & 14 & 45.2 \\
\hline
\end{tabular}

\begin{tabular}{lcccccc}
\hline $\begin{array}{l}\text { Riwayat } \\
\text { Merokok }\end{array}$ & & & & & & \\
Never & 8 & 32 & 8 & 32 & 9 & 36 \\
Past & 1 & 33.3 & 0 & 0 & 2 & 66.7 \\
Active & 0 & 0 & 1 & 25 & 3 & 75 \\
\hline Diet & & & & & & \\
Yes & 1 & 11.2 & 4 & 44.4 & 4 & 43.4 \\
No & 8 & 34.8 & 5 & 21.7 & 10 & 44.5 \\
\hline
\end{tabular}

Table 6 indicates that type 2 diabetics with ABI values of the right extremity categories borderline and abnormal are female gender, abnormal values are high in diabetics who do not routinely consume anti diabetic drugs, abnormal ABI values are many in patients who do not exercise regularly, abnormal $\mathrm{ABI}$ values are many in patients who have never performed foot therapy, and abnormal ABI values are high in patients who do not carry out diet.

\section{DISCUSSION}

Description of ABI values in patients with diabetes mellitus

The results of this study indicate that the ABI values of right extremity in type 2 diabetes mellitus in Village of KepanjenKidul and Karangsari in normal category are 8 peoples $(25 \%)$, borderline
11 peoples (34.4\%) and abnormal 13 peoples (40, $6 \%$ ). While the value of ABI on left extremities in normal category 9 peoples $(28.1 \%)$, borderline 9 peoples $(28.1 \%)$ and abnormal 14 peoples $(43.8 \%)$.

Diabetic foot with ulcer is a frequent complication of diabetes. Diabetic foot ulcers are caused by the process of peripheral neuropathy, peripheral arterial disease, or a combination of both. Thus increasing morbidity, mortality, and reducing the quality of life of patients (Perkeni, 2015). Therefore, in diabetesmellitus needs to be done vascular examination of the foot or commonly called ABI examination.Ankle Brachial Index is a noninvasive vascular screening test for identifying large blood vessels, peripheral arterial disease by comparing cytologic blood pressure in the ankle to systolic pressure in the brachialis performed using Doppler Vascular. The goal of ABI examination is to support the diagnosis of vascular disease by providing an objective indicator of arterial perfusion to the lower extremities. Abnormal ABI values reflect atherosclerosis. (WOCN Wound Commite, 2012).

Peripheral vascular damage in the hands and feet, called Peripheral Vascular Disease (PVD), can occur earlier and the process is faster in people with diabetes mellitus than those who do not have diabetes mellitus. The pulse of the blood vessels in the leg feels weak or does not feel at all. If diabetes lasts for more than 10 years, a third of men and women may develop the disorder (Ndraha, 2014).

Hyperglycaemia that occurs due to excessive carbohydrate input, reduced glucose consumption in the tissues, increased liver glucose production, long-lasting insulin defects will initiate various forms of abnormalities such as neuropathy and peripheral arterial disease (PAD) (Criqui, 2011). The presence of this PAD will reduce arterial perfusion to the lower extremities. This decrease of perfusion is usually characterized by the loss of peripheral pulsation and the presence of clinical manifestations such as claudication intermittent (pain of walking time, and improved at rest), will facilitate the development of infection, ulceration and wound healing, can even lead to gangrene which leads to amputation foot (Creager, 2012).

Cross-tabulation of $\mathrm{ABI}$ values by gender, anti diabetic drugs consumtions, exercise, smoking history, foot therapy, and diet

Cross-rabulation result of $\mathrm{ABI}$ of right and left extremities by sex, anti diabetic drugs consumtions, exercise, smoing history, foot therapy and diet in 
people with diabetes mellitus is no significant difference.

Half of the respondents were male. Increased risk of PAD in men is likely due to previous smoking history. The data obtained as many as 3 respondents (9.4\%) never smoked and now they have stopped smoking, and 4 respondents $(12.5 \%)$ are active smokers. Cigarette smoke is known to cause vascular endothelial dysfunction, increase the concentration of fibrinogen, decrease fibrinolytic activity and increase platelet aggregation. Smokers are three times higher risk for intermittent claudication and show symptoms 10 years earlier than nonsmokers. (O'Donnell et al, 2011).

A total of $7(41.2 \%)$ respondents with abnormal ABI values on right extremity were respondents with non-routine categories consuming anti diabetic drugs, as did the left limb. Number of respondents with abnormal $\mathrm{ABI}$ score on right exercise non-exercise routine as many as $8(42.1 \%)$ respondents, while abnormal $\mathrm{ABI}$ score on left extremity in non-routine respondents exercised as many as $9(47.4 \%)$ respondents. The number of respondents with abnormal $\mathrm{ABI}$ values on the right extremity who had never performed foot therapy were $13(41.9 \%)$ respondents. While respondents with abnormal $\mathrm{ABI}$ values on the left extremity who never performed foot therapy as much as 14 (45.2\%) respondents. Number of respondents with abnormal ABI value on right extremity who did not implement diabetes diet as many as $9(39.2 \%)$ respondents. While a number of respondents with abnormal ABI value on left extremity that did not implement diet of diabetes mellitus counted 10 (44.5\%) of respondents.

Approximately $70 \%$ of cases of foot ulcers are the main causes of Chronic Vein Insufficiency (CVI), and about $20 \%$ to $25 \%$ with arterial or mixed diseases (Nelson and Bradley, 2003; Brayant\& Nix 2007). Risk factors for venous blood disorders in patients with diabetes mellitus include age over 50 years, more women than men, heart problems, obesity, and others (Scemons\&Elston, 2009).

Key strategies for considering venous insufficiency and hypertension, therapy, management; Additional actions. For body health, pharmacological agents, and routine leg elevation (Brayant\& Nix 2007)

\section{CONCLUSIONS AND SUGGESTIONS}

\section{Conclusion}

The result of the research have shown that the most of the respondents who have been done ABI examination results are abnormal on the left and right extremities. Additional data showed that some respondents did not adhere to diet, did not do foot therapy, did not exercise regulary, and did not routinely consume diabetic drugs.

\section{Suggestion}

Based on the research that has been done, obtained ABI examination results in people with diabetes mellitus mostly in the category of borderline and abnormal. Some factors that may affect the results include lack of adherence in the diet, not exercise routine, never do foot therapy, and not routinely in consuming anti diabetic drugs. Therefore, for nurse specially nurse Specialist of Medical Nursing of Surgical and Wound Care is expected to conduct comprehensive study in order to formulate a comprehensive action plan which of course to overcome the problem that happened in diabetesmellitus.

\section{REFERENCE}

Boulton AJ. et al.2008. Comprehensive Foot Examination andRisk Assessment. Diabetes Care. 31: 167985.

Brayant, RA. \& Nix, DP. 2007. Acute \& Chronic Wounds. Current Management Concepts. Third Edition. United States of America: Mosby Elsevier.

Brownrigg JR. et al. 2012. The Association of Ulceration of The Foot With Cardiovascular and All-Cause Mortality in Patients with Diabetes: A MetaAnalysis. Diabetalogia. 55 (11): 2906-12.

Carville, K. 2007. Wound Care Manual. 5th Edition. Western Australia: Silver Chain Foundation.

Creager, M.A. 2012. Peripheral Artery Disease a Text Book of Cardiovascular Medicine. 9th ed. Philadelphia, USA: Elsevier Saunders. pp 1338-56

Criqui, MH., 2011. Peripheral Arterial-Disease-Epidemiological Aspects. Vasc Med. 6: 3-7.

Migliacci, R. et al. 2008. Ankle-Brachial Index Measured By Palpation For The Diagnosis Of Peripheral Arterial Disease. Fam Pract. 25:228-232

Ndraha, S. 2014. Diabetes Melitus Tipe 2 dan Tatalaksana Terkini. Midicinus Vol. 27, No. 2.

O'Donnell ME., et al. 2011. Optimal Management Of Peripheral Arterial Disease For The Non Specialist.Ulster Med J. ; 80(1): 33-41. 
Perkeni. 2015. Pengelolaan dan Pencegahan Diabetes Melitus Tipe 2 di Indonesia. Jakarta: Perkeni

Potier, L., et al. 2011. Use and Utility of Akle Brachial Index in Patients with Diabetes. Eur J Vasc Endovasc Surg. 41(1): 110-16.

Prompers, L. et al. 2008. Resource Utilisation and Cost Associated with The Treatment of Diabetic Foot Ulcers. Diabetologia. 51: 1826-34.
Smeltzer, et al. 2010. Brunner \&Suddarth's Textbook of Medical Surgical Nursing. $12^{\text {th }} e d$. Philadelphia: Lippincott, 1197.

WOCN Wound Commite. 2012. Ankle Brachial Index. Quick Reference Guide for Clinicians. J Wound Ostomy Continence Nurs. 39(2S): S21-S29. 